Ludwig, S. C., S. Roos, C. J. Rollie, and D. Baines. 2020. Long-term changes in the abundance and breeding success of raptors and ravens in periods of varying management of a Scottish grouse moor. Avian Conservation and Ecology 15(1):21. https://doi.org/10.5751/ACE-01568-150121 Copyright (C) 2020 by the author(s). Published here under license by the Resilience Alliance.

\title{
Long-term changes in the abundance and breeding success of raptors and ravens in periods of varying management of a Scottish grouse moor
}

\author{
Sonja C. Ludwig ${ }^{1,2}$, Staffan Roos ${ }^{3,4}$, Chris J. Rollie ${ }^{5}$ and David Baines ${ }^{1}$ \\ ${ }^{1}$ Game and Wildlife Conservation Trust, UK, ${ }^{2}$ Langholm Moor Demonstration Project, UK, ${ }^{3}$ RSPB Centre for Conservation \\ Science, RSPB Scotland, UK, ${ }^{4}$ Swedish Species Information Center, Swedish University of Agricultural Sciences, Sweden, \\ ${ }^{5}$ Dumfries \& Galloway Raptor Study Group, UK
}

\begin{abstract}
Management of heather moorland for driven Red Grouse (Lagopus lagopus scotica) shooting in the British uplands may benefit some raptors by reducing predation risk, especially when breeding, and by increasing food availability. We describe changes in abundance and breeding success of four raptor species and Common Raven (Corvus corax) during a 27-year study on a grouse moor in southwest Scotland in relation to whether or not the moor was managed by gamekeepers. Ground-nesting raptors, Hen Harrier (Circus cyaneus) and Merlin (Falco columbarius), increased during periods of grouse moor management and had a higher proportion of successful nesting attempts. Predation was the main apparent cause of breeding failure. In contrast, grouse moor management did not influence either abundance or breeding success of tree- and crag-nesting species, i.e., Peregrine (Falco peregrinus), Common Buzzard (Buteo buteo), and Raven. Buzzard sightings increased during the study, in line with their national recovery, whereas Peregrine and Raven showed little change in abundance. The results of our study highlight that management for Red Grouse can benefit both Hen Harrier and Merlin. However, on a UK scale these benefits to Hen Harriers, but not Merlin, are outweighed by their illegal killing, caused by fears that their consumption of Red Grouse can undermine the economics of grouse moor management.
\end{abstract}

\section{Changements de longue date dans l'abondance et le succès de reproduction d'oiseaux de proie et des corbeaux sous différents scénarios de gestion d'une lande pour le Lagopède des saules en Écosse}

RÉSUMÉ. La gestion des landes à bruyère pour la chasse au Lagopède des saules (Lagopus lagopus scotica) dans les hautes terres britanniques pourrait profiter à certains oiseaux de proie en réduisant le risque de prédation, en particulier au moment de la reproduction, et en augmentant la disponibilité des ressources alimentaires. Nous décrivons les changements en matière d'abondance et de succès de reproduction de quatre espèces d'oiseaux de proie et du Grand Corbeau (Corvus corax) dans le cadre d'une étude de 27 ans sur une lande à lagopèdes dans le sud-ouest de l'Écosse, en relation avec le fait que celle-ci était ou n'était pas gérée par des gardes-chasse. Le nombre d'oiseaux de proie nichant au sol, soit le Busard Saint-Martin (Circus cyaneus) et le Faucon émerillon (Falco columbarius), a augmenté au cours des périodes dans lesquelles la lande était gérée, et nous avons observé une plus grande proportion de tentatives réussies de nidification. La prédation s'est révélée être la principale cause apparente des échecs de nidification. À l'opposé, la gestion de la lande pour les lagopèdes n'a pas influé sur l'abondance ni le succès de reproduction des espèces nichant dans les arbres ou les rochers, soit le Faucon pèlerin (Falco peregrinus), la Buse variable (Buteo buteo) et le Grand Corbeau. Les observations de buses ont augmenté au cours l'étude, conformément au rétablissement de l'espèce à l'échelle nationale, tandis que l'abondance du Faucon pèlerin et du corbeau a peu changé. Les résultats de notre étude soulignent que la gestion du Lagopède des saules peut profiter à la fois au Busard Saint-Martin et au Faucon émerillon. Toutefois, à l'échelle du Royaume-Uni, ces avantages pour le busard, mais pas pour le Faucon émerillon, sont contrebalancés par son abattage illégal, causé par la crainte que leur consommation de lagopèdes puisse compromettre le marché économique de la gestion de la lande pour les lagopèdes.

Key Words: ground-nesting; predation; predator control; prey abundance; population dynamics

\section{INTRODUCTION}

Raptor densities are naturally limited by the availability of food and nest sites, but can be suppressed by other factors such as human activities or predation (Newton 1979, 2003, Stroud 2003, Sergio and Hiraldo 2008). In stable environments, the breeding populations of many raptor species such as Peregrine Falcon (Falco peregrinus) and Golden Eagle (Aquila chrysaetos) show a high degree of stability with regular spacing of territorial pairs (Ratcliffe 1993, Newton 2003), while species depending on cyclic prey may show annual fluctuations in breeding density, for example Gyrfalcon (Falco rusticolus; Nielsen 1999) and Eurasian Kestrel (Falco tinnunculus; Korpimaki and Norrdahl 1991).

One human activity that may influence raptor densities at a landscape scale is gamebird management, as shown for released gamebirds (Pringle et al. 2019). Here, we focus on the management of heather Calluna vulgaris moorland for driven Red Grouse Lagopus lagopus scotica (an indigenous, nonreleased gamebird) shooting in the British uplands. On these "grouse moors," 
gamekeepers routinely remove generalist predators including red fox (Vulpes vulpes), stoat (Mustela erminea), weasel (M. nivalis), and Carrion Crow (Corvus corone) to maximize postbreeding Red Grouse densities for shooting (Hudson and Newborn 1995). Predator removal has been shown to increase breeding success and abundance in a range of bird species (Newton 1998, Fletcher et al. 2010, Smith et al. 2010), although some studies failed to find an effect (e.g., Bodey et al. 2011). So far, evidence of populationlevel effects of predation on raptors is rare and largely restricted to intraguild predation (Petty et al. 2003, Sergio et al. 2003, Chakarov and Krüger 2010, Roos et al. 2018). Nevertheless, nest predation can be an important cause of breeding failure in some raptor species (Rebecca et al. 1992, McMillan 2014) and may influence numbers and breeding success. In Britain, the main predators of raptor eggs and chicks include red fox, mustelids, corvids, owls, and other raptors (reviewed by Roos et al. 2018). The level of nest predation is influenced by the abundance of predators (e.g., Roos and Pärt 2004) and accessibility of nest-sites, with nests on the ground being vulnerable to more mammalian predators than those in trees or on other elevated structures (Newton et al. 1978, Söderström et al. 1998).

Grouse moor management increases the abundance not only of Red Grouse, but also other ground-nesting birds such as waders and some passerines (Tharme et al. 2001, Fletcher et al. 2010, Douglas et al. 2014). Raptors may thus not only benefit from reduced predation risk associated with grouse moors, especially those species nesting on the ground (Baines and Richardson 2013), but also from greater food availability (Redpath et al. 2002). However, driven grouse moors have also been associated with the illegal killing of raptors that predate Red Grouse, notably Hen Harrier (Circus cyaneus), Peregrine, and Golden Eagle (e.g., Etheridge et al. 1997, Amar et al. 2012, Whitfield and Fielding 2017) because the consumption of Red Grouse by some of these raptors can reduce Red Grouse densities to the extent that they undermine grouse moor economics (Redpath and Thirgood 1997, Thirgood et al. 2000a, New et al. 2012). Previous studies found that Hen Harriers had lower breeding success and survival on grouse moors compared to other heather-dominated moors that provide suitable nesting habitat (Etheridge et al. 1997, Summers et al. 2003), and the pattern of satellite-tagged Hen Harrier disappearances suggests that illegal killing on British grouse moors still persists (Murgatroyd et al. 2019). In contrast, the cessation of grouse moor management on a moor where raptors were protected led to a $50 \%$ decrease in Hen Harrier breeding success, which was mostly attributed to increased fox predation (Baines and Richardson 2013).

Long-term monitoring is fundamental in assessing changes in breeding populations in response to environmental changes, including land management, and can provide important insights into ecological processes, although it has some limitations in inferring causality in comparison with experimental approaches. Here, we describe changes in the abundance of four raptor species and Common Raven (Corvus corax), a protected corvid, during a 27-year study on a grouse moor in southwest Scotland, where raptors have not been illegally killed since 1990 (Thirgood and Redpath 2000). In contrast to previous between-moor comparisons, our study enabled us to semiexperimentally test the responses of raptors and Raven to successive periods of grouse moor management, i.e., its cessation, restoration, and further cessation at the same site. First, we examined changes in both numbers and breeding success of two ground-nesting species (Hen Harrier and Merlin [Falco columbarius]) and three tree- or cragnesting species (Peregrine, Common Buzzard [Buteo buteo], and Raven) in relation to these periodic changes in grouse moor management. We predicted that both breeding success and abundance of ground-nesting raptors would be higher when the moor was actively managed for Red Grouse, with gamekeepers reducing numbers of potential predators, especially foxes. Second, we tested whether changes in the abundance of key prey species (passerines, Red Grouse, and field voles (Microtus agrestis) could have contributed to the observed changes in abundance and breeding success of ground-nesting raptors. We hypothesized that changes in prey abundance would influence brood size at fledging (Newton 1979, Salamolard et al. 2000), while changes in nest predation rates, which often result in the loss of the whole clutch or brood, would influence the proportion of successful breeding attempts.

\section{METHODS}

\section{Study site}

The study was conducted on Langholm Moor in southwest Scotland $\left(55.219^{\circ} \mathrm{N}, 2.885^{\circ} \mathrm{W}\right)$, on part of the area studied by Redpath and Thirgood (1997). The $115-\mathrm{km}^{2}$ site included most of the $76-\mathrm{km}^{2}$ Langholm-Newcastleton Hills Site of Special Scientific Interest, notified in 1985 for the upland breeding bird and habitat assemblage, and Special Protection Area, notified in 2001 for breeding Hen Harriers. The vegetation consisted of a mosaic of heather moorland ( $24 \%$, heath and blanket bog) and acid grassland $(70 \%)$, interspersed with wooded stream gullies, agriculturally improved grassland $(3 \%)$, and patches of commercial coniferous forest and mixed deciduous woodland $(3 \%)$. In the wider area, the study site was surrounded by forest and grassland.

During the study period (1992-2018), Langholm Moor was managed for driven Red Grouse shooting until February 1999 and then from April 2008 to February 2016, although Red Grouse were last shot in 1996 (Thirgood et al. 2000b, Ludwig et al. 2017). In the intermediate years, 2000-2007, and in 2017-2018, no fulltime gamekeepers were employed, and the moor was not managed for Red Grouse.

When managed for Red Grouse, gamekeepers legally controlled generalist predators on the whole $115-\mathrm{km}^{2}$ site and managed the heather habitat by rotational burning or cutting more mature stands of heather to provide a mosaic of heather height and structures that may benefit breeding Red Grouse (Robertson et al. 2017, Ludwig et al. 2018a). Predator control was carried out throughout the year. On average, gamekeepers removed $187 \pm 20$ foxes and $308 \pm 18$ Carrion Crows per annum between 1992 and 1999, and $189 \pm 22$ foxes and $260 \pm 22$ Carrion Crows per annum between 2008 and 2015, with annual bags remaining largely constant across periods of predator control. The latter suggests some compensatory movement of predators into the cull area, however, mean abundance indices of foxes and Carrion Crows during the breeding season were reduced in managed periods by $65 \%$ and $62 \%$, respectively, compared to the unmanaged period in between (Ludwig et al. 2017). This is consistent with Porteus et al. (2019), who showed that restricted-area culling successfully 
suppressed local fox densities on 22 game-shooting estates, including one upland estate where fox density during the nesting period was reduced to $64 \%$ of the estimated carrying capacity.

Between 2008 and 2014, gamekeepers also provided grit coated with an anthelminthic drug to help control the intestinal parasite Trichostrongylus tenuis in Red Grouse, which can reduce Red Grouse survival and breeding success (Hudson et al. 1998, Newborn and Foster 2002). To reduce predation of Red Grouse chicks by Hen Harriers, diversionary food was experimentally provided to half of the Hen Harrier broods in 1998-1999 (Redpath et al. 2001) and to all broods in 2008-2015 (Ludwig et al. 2018b). Owing to the nonexperimental design of our study, it was not possible to test for the relative effects of these potentially confounding management measures, hence we focused on the overall effect of grouse moor management.

Raptors recorded breeding on the study area were Hen Harrier, Peregrine, Buzzard, Merlin, Kestrel, and Eurasian Sparrowhawk (Accipiter nisus), although the latter was rarely seen. Northern Goshawk (Accipiter gentilis) only foraged on the study area, but one to three pairs were known to nest within $1 \mathrm{~km}$ in adjacent forests. Numbers and breeding success of owls (Short-eared Owl [Asio flammeus], Tawny Owl [Strix aluco], Long-eared Owl [A. otus], and Barn Owl [Tyto alba]), together with Kestrel and Sparrowhawk, were not monitored and are not considered further.

\section{Raptor breeding numbers and breeding success}

Breeding Hen Harrier and Merlin were recorded by observing birds displaying, nest-building, transporting prey, or performing food-passes in April to June (Hardey et al. 2013). For Hen Harriers, we focused on breeding females because male harriers can be polygynous; during our study 25 out of 147 males had two females and two males had three. Breeding pairs of Peregrine, Buzzard, and Raven were determined by checking occupancy of traditional and other suitable nest sites. Hen Harrier, Merlin, and Peregrine were monitored annually from 1992, except no data were available for Merlin in 2001-2004 or for Peregrine in 2001 (an outbreak of bovine foot-and-mouth disease restricted monitoring in 2001). In addition, no information was available on the occupancy of one Peregrine nest site in 1993-1999. Raven nests were recorded in 1994 and then annually from 1999 (except 2001). Buzzard nests were monitored for the purpose of one study in 1993 (Graham et al. 1995) and then annually from 2008, however, search effort for nests varied between years depending on other fieldwork commitments and nests were often found after the onset of incubation.

Wherever possible, breeding attempts (including replacement clutches) were monitored from laying until fledging of chicks to determine their outcome (successful = fledged at least one chick) and, for successful attempts, brood size at fledging. Hen Harrier nests were visited at least three times: during incubation to record clutch size, within a week after hatching to record the number of chicks hatched, and shortly before fledging to record the number of chicks reared. Five attempts by Hen Harrier and two by Merlin failed early, before a nest visit could confirm a clutch, but were included when there was sufficient observational evidence to suggest that the female had started laying, i.e., courtship display and nest-building followed by the male feeding the female at the nest site ("proven" breeding, see Hardey et al. 2013). Peregrine nest sites were visited at least twice, first to determine occupancy and second to record the number of chicks reared. For Merlin, Buzzard, and Raven, nest-visit frequency varied, and breeding outcome was often determined by observations of fledglings near the nest, or by droppings below the nest (Buzzard and Raven) indicating large chicks. In these cases, it was often impossible to determine the exact brood size. All Hen Harrier nests $(\mathrm{N}=192)$ and $96 \%$ of Merlin nests $(\mathrm{N}=73)$ were located on the ground, with three Merlin pairs using old crow nests in trees.

For unsuccessful breeding attempts by Hen Harrier and Merlin, the stage of failure, i.e., clutch or brood, and the likely cause were recorded. Causes of failure were assessed in situ based on field signs at nests, for Hen Harriers complemented by camera footage in 2008-2018. Predators of well-grown chicks and breeding females were identified following Thirgood et al. (1998), with bitten feathers, puncture wounds on carcasses, or the presence of fresh scats suggesting mammalian predators, and plucked feathers suggesting raptors. Clutch predators were identified from eggshell remains following Green et al. (1987). Clutches were considered deserted when eggs remained intact and the female was still alive. When clutches or broods disappeared without signs, nests were assumed predated and classified as "unknown predator." When the cause of failure could not be determined, e.g., when nest visits were delayed after failure, it was classified as "unknown." However, evidence of the cause of failure based on field signs at nests may be biased by factors such as scavenging and should thus be considered "apparent causes of failure."

\section{Raptor abundance indices}

Because nest-based monitoring for Buzzards was restricted across years and varied in relation to search effort, we obtained annual abundance indices of Buzzard, and for comparison also of Hen Harrier and Merlin, from breeding bird surveys on 15 1-km grid squares on moorland habitat (only 12 squares were counted in 1997 and 2001, and 14 in 1998; Thirgood et al. 1995). Between 1992 and 2002, squares were surveyed once between late May and mid-July, but from 2003 were surveyed twice (mid-April to mid-May, repeated mid-May to mid-June) following BTO/RSPB/JNCC Breeding Bird Survey methods (BBS; Harris et al. 2018). For consistency across the whole time series, we used the data from the second visit for analyses. Within each square, the observer walked along two parallel $1-\mathrm{km}$ transects, separated by $500 \mathrm{~m}$, recording birds seen or heard. Surveys were conducted only in suitable weather conditions, avoiding strong wind, rain, and poor visibility. For each year and species, we summed the sightings from all squares, and calculated annual abundance indices as birds $\mathrm{km}^{-1}$ to account for variation in the number of squares counted.

\section{Abundance of main raptor prey species}

An annual index for passerine abundance (birds km$~^{-1}$ ) was obtained from Breeding Bird Surveys as above, using the total number of Meadow Pipits (Anthus pratensis) and Skylarks (Alauda arvensis) counted, these being the main passerine prey species for Hen Harrier and Merlin recorded in earlier studies (e.g., Redpath and Thirgood 1997, Heavisides et al. 2017).

Field vole abundance was estimated annually from 1992 through snap-trapping in late March to early April (Redpath et al. 1995). Fifty unbaited traps were placed at 5-m intervals over two nights along each of 10 transects on moorland habitat, giving a total of 
1000 trap nights per annum. The vole index was then calculated as voles 100 trap nights $^{-1}$.

Red Grouse were counted annually from 1992 in March and July on ten $0.5 \mathrm{~km}^{2}$ blocks of representative moorland habitat (Redpath and Thirgood 1997). Within each count block, the observer walked parallel transects $150 \mathrm{~m}$ apart (mean transect length per block: $3.3 \pm 0.2 \mathrm{~km}$ ), while a pointing dog quartered the ground on either side of the transect searching for Red Grouse. Birds counted in July were aged as young or adult by size and plumage characteristics (Cramp and Simmons 1980). We used the number of adults counted in March to estimate prebreeding density (birds $\mathrm{km}^{-2}$ ), and the number of young counted in July to estimate Red Grouse chick density (chicks km${ }^{-2}$ ).

\section{Data analysis}

To compare the periods with grouse moor management ("managed") with those without ("unmanaged"), as well as test for differences between the two managed periods, we defined "grouse moor management" as a factor with three levels; "managed 1" (1992-1999), "managed 2" (2008-2016), and "unmanaged" (2000-2007 and 2017-2018). The two unmanaged periods (2000-2007 and 2017-2018) were pooled as a sample size of only two years in the later period was insufficient for testing between-period differences. However, when analyzing trends in breeding numbers within management periods, 2017 and 2018 were excluded from the unmanaged period because they did not directly extend the trend from 2000 to 2007.

\section{Breeding abundance}

To assess whether trends in breeding abundance varied between managed and unmanaged periods (excluding 2017-2018), we used Generalized Linear Models (GLM) with a Poisson distribution and logarithmic link function. For each species in turn (except Buzzards, see below), we included the annual number of breeding pairs (nesting females for Hen Harriers) as the response variable, year as a covariate, "grouse moor management" as a factor, and a year $\mathrm{x}$ grouse moor management interaction. A significant interaction term would suggest that trends in breeding abundance differed between periods of different management. For Raven, we excluded the first managed period from the analysis owing to insufficient data. We then dropped "grouse moor management" from the models and analyzed changes in breeding abundance either within each management period, if the interaction was significant, or across the whole study period. Average annual rates of change $r$ were calculated from the slope $a$ of year as $r=\mathrm{e}^{a}-1$, expressed as a percentage, and approximated $\operatorname{SE}(r)$ as ${ }^{a} \operatorname{SE}(a)$ (Seber 1982).

For Buzzards, data on breeding pairs were largely restricted to the second managed period, and thus insufficient to test for year $x$ grouse moor management interactions. Instead, we used Buzzard abundance indices derived from breeding bird surveys in the models, including the annual count as the response variable, offset by $\ln (\mathrm{km})$ to account for variation in the total length of transects counted.

To test whether the observed changes in Hen Harrier and Merlin breeding numbers were associated with changes in the availability of their main prey (passerines, Red Grouse, voles), we then included the respective prey abundance indices as covariates into the original models (including the year $\mathrm{x}$ grouse moor management interaction). For Hen Harriers, a passerine-vole specialist that can also prey on larger birds (Watson 1977), we included all three prey abundance indices (passerines, prebreeding Red Grouse, voles), whereas for Merlins, a passerine specialist (Newton et al. 1984), we only included the passerine index.

\section{Breeding success}

Differences in the average annual proportion of successful breeding attempts between managed and unmanaged periods were considered in GLMs with binomial distribution and logit link function, where we defined the number of successful attempts (fledged $\geq 1$ chick) per year as the number of successes, and the annual number of breeding attempts with a known fate, i.e., successful or failed, as the number of trials. "Grouse moor management" was included as an explanatory factor. For successful attempts where the number of fledged young was known, annual brood sizes at fledging were compared between managed and unmanaged periods by Poisson regression using a logarithmic link function, with total number of young per year as the response variable, $\ln$ (number of broods) as offset and "grouse moor management" as an explanatory factor. To assess whether any differences in brood size at fledging resulted from either changes in clutch size, chick survival, or both, we repeated this analysis, for Hen Harrier, for annual clutch sizes, with the total number of eggs laid per year as the response variable, $\ln$ (number of clutches) as offset and "grouse moor management" as an explanatory factor.

For Hen Harrier and Peregrine, we also calculated overall productivity, i.e., the total number of young fledged breeding attempt ${ }^{-1}$, which is the product of the proportion of successful attempts and brood size and can vary in relation to changes in either rate. For Merlin, Buzzard, and Raven, records on brood size of successful pairs were incomplete, which may have biased overall productivity toward pairs that failed and thus likely underestimated productivity. Overall productivity of Hen Harrier and Peregrine was analyzed using GLMs with Poisson distribution and logarithmic link function, with the total number of chicks fledged per year as response variable, $\ln$ (number of attempts with known fate) as offset, and "grouse moor management" as an explanatory factor.

As above, we then tested whether the observed changes in Hen Harrier and Merlin breeding success, i.e., the proportion of successful breeding attempts, could be explained by changes in prey availability by including the abundance indices for passerines, Red Grouse chicks, and voles (for Merlin, passerines only) as additional covariates into the models.

Finally, we compared the frequency of Hen Harrier and Merlin breeding failures at each stage (with eggs, with chicks) between managed and unmanaged periods using Chi-square tests. Early failures were assigned to failure with eggs because females were assumed to have started laying. For each species and failure stage, we then summarized the apparent causes of breeding failure during managed and unmanaged periods.

\section{Variation in prey abundance}

To test whether prey availability varied in relation to grouse moor management, we included the abundance indices for passerines, Red Grouse, and voles, in turn, as response variable in a GLM with normal errors and identity link function, and "grouse moor management" as a two-level factor (managed, unmanaged). 
Table 1. Effect of grouse moor management and prey abundance on changes in Hen Harrier (Circus cyaneus) and Merlin (Falco columbarius) breeding numbers and percentage of successful breeding attempts. The Red Grouse (Lagopus lagopus scotica) index was based on adult prebreeding density when analyzing Hen Harrier breeding abundance, and on chick density when analyzing Hen Harrier breeding success. Values are parameter estimates \pm SE. Significant p-values are highlighted in bold.

\begin{tabular}{|c|c|c|c|}
\hline Model & Variable & Hen Harrier & Merlin \\
\hline Breeding abundance & $\begin{array}{l}\text { Year x Grouse moor management } \\
\text { Passerine index } \\
\text { Grouse index } \\
\text { Vole index }\end{array}$ & $\begin{array}{l}\mathrm{F}_{2,14}=12.49, \mathbf{p}<\mathbf{0 . 0 0 1} \\
0.001 \pm 0.016 \\
\mathrm{~F}_{1,14}=0.18, \mathrm{p}=0.675 \\
0.065 \pm 0.023 \\
\mathrm{~F}_{1,14}=8.29, \mathbf{p}=\mathbf{0 . 0 1 2} \\
0.015 \pm 0.067 \\
\mathrm{~F}_{1,14}=0.05, \mathrm{p}=0.826\end{array}$ & $\begin{array}{l}\mathrm{F}_{2,14}=5.72, \mathbf{p}=\mathbf{0 . 0 1 5} \\
-0.063 \pm 0.056 \\
\mathrm{~F}_{1,14}=1.29, \mathrm{p}=0.276\end{array}$ \\
\hline Breeding success & $\begin{array}{l}\text { Grouse moor management } \\
\text { Passerine index } \\
\text { Grouse index } \\
\text { Vole index }\end{array}$ & $\begin{array}{l}\mathrm{F}_{2,21}=4.44, \mathbf{p}=\mathbf{0 . 0 2 5} \\
0.054 \pm 0.045 \\
\mathrm{~F}_{1,21}=1.43, \mathrm{p}=0.246 \\
-0.021 \pm 0.024 \\
\mathrm{~F}_{1,21}=0.75, \mathrm{p}=0.397 \\
-0.064 \pm 0.190 \\
\mathrm{~F}_{1,21}=0.11, \mathrm{p}=0.738\end{array}$ & $\begin{array}{l}\mathrm{F}_{2,19}=5.86, \mathbf{p}=\mathbf{0 . 0 1 0} \\
0.018 \pm 0.042 \\
\mathrm{~F}_{1,19}=0.19, \mathrm{p}=0.667\end{array}$ \\
\hline
\end{tabular}

All analyses were conducted using GenStat 19.1 (VSN International 2018). Poisson models were tested for overdispersion by testing the deviance as $\mathrm{Chi}^{2}$ for goodness-offit, and, when the latter was significant, adjusted by estimating the dispersion parameter from the residual mean square of the fitted model (using an $\mathrm{F}$ distribution). All means are given \pm one standard error.

For Hen Harriers, some of the analyses include previously published data on breeding abundance and the proportion of successful breeding attempts (1992-2015; Ludwig et al. 2017), which have been expanded by the inclusion of recent years, allowing us to consider a further change in grouse moor management.

\section{RESULTS}

\section{Breeding abundance}

Average annual rates of change in abundance of breeding female Hen Harrier varied in relation to periods of different grouse moor management (year* period interaction: $\mathrm{F}_{2,19}=7.15, \mathrm{p}=0.005$ ), and those of Merlin pairs showed the same, but not significant, tendency (year*period interaction: $\mathrm{F}_{2,15}=3.25, \mathrm{p}=0.067$ ). When including prey abundance indices into the models, the year* period interaction was significant for both species (Table 1). In addition, the number of breeding female Hen Harriers was positively associated with prebreeding Red Grouse density, but not with passerine or vole indices, while the number of Merlin pairs showed no association with the passerine index (Table 1).

The number of female Hen Harriers increased on average by 21 $\pm 8 \%$ per annum between 1992 and $1999\left(\mathrm{~F}_{1,6}=8.52, \mathrm{p}=0.027\right)$, peaking at 20 females in 1997 (Fig. 1a; see Table A1.1 in Appendix 1 for model output). After grouse moor management ceased, numbers declined by $16 \pm 6 \%$ per annum between 2000 and 2007 $\left(\mathrm{F}_{1,6}=6.38, \mathrm{p}=0.045\right)$, but increased again by $29 \pm 12 \%$ per annum between 2008 and 2016 when grouse moor management resumed $\left(\mathrm{F}_{1,7}=7.84, \mathrm{p}=0.026\right)$, peaking at 12 females in 2014 Since grouse moor management ceased again in 2016, Hen Harrier numbers have declined from nine females in 2017 to four females in 2018 . However, the declines in both unmanaged periods already started at the end of the preceding managed periods (see Fig. 1a). The number of Merlin pairs showed no significant trend during the first managed period $\left(3 \pm 4 \%\right.$ per annum; $F_{1,6}=0.54$, $p=0.49)$ and then remained low at only one to two pairs during the unmanaged period. However, when grouse moor management resumed, the number of breeding pairs increased by $22 \pm 7 \%$ per annum between 2008 and $2016\left(\mathrm{~F}_{1,7}=12.79, \mathrm{p}=0.009\right)$, peaking at 10 pairs in 2015 (Fig. 1a). The number of breeding Hen Harrier, but not Merlin, was correlated with abundance indices obtained from the breeding bird surveys (Hen Harrier: $r=0.75, n=27, p$ $<0.001$; Merlin: $\mathrm{r}=0.25, \mathrm{n}=23, \mathrm{p}=0.26$ ).

Annual rates of change in abundance of breeding Peregrine and Raven did not vary in relation to periods of different grouse moor management (year* period interaction: Peregrine: $\chi_{2,18}^{2}=0.99, \mathrm{p}$ $=0.61$; Raven: $\left.\chi_{1,12}^{2}=0.06, p=0.81\right)$. Peregrine numbers on the study area fluctuated between two and four pairs during the first managed period and the unmanaged period (although we had no information on occupancy of one site between 1993 and 1999), and then remained at two pairs during the second managed period (Fig. 1b). However, there was no significant overall trend in Peregrine abundance between 1992 and 2018 (-2 $\pm 2 \%$ per annum; $\chi_{1,24}^{2}=2.44, p=0.12$; see Table A1.1 in Appendix 1 for model output). Raven numbers increased from one pair in 1994 to five pairs in 1999 but remained stable thereafter (Fig. 1b), showing no overall trend between 1994 and $2018\left(1 \pm 2 \%\right.$ per annum; $\chi_{1,18}^{2}=$ $0.61, p=0.43)$. In contrast, Buzzard abundance increased from four pairs in 1993 to 16 pairs in 2018 (Fig. 1) at a rate of $5 \pm 1 \%$ per annum $\left(\mathrm{F}_{1,10}=15.57, \mathrm{p}=0.003\right)$. The number of Buzzard pairs, excluding 2014 when monitoring effort was limited owing to other fieldwork commitments, was correlated with abundance indices obtained from breeding bird surveys $(r=0.69, n=11, p$ 
Fig. 1. Changes in breeding numbers of raptors and Common Raven (Corvus corax) at Langholm 1992-2018, (a) groundnesting, (b) tree- and crag-nesting. Years with grouse moor management, which involves predator control, are shaded grey (2008 considered unkeepered when analyzing breeding numbers). Between 1993 and 1999, we had no information on occupancy of one Peregrine Falcon (Falco peregrinus) site, hence there may have been one additional pair in these years. Trendlines show significant linear trends (a) within management periods (dotted black line: Hen Harrier [Circus cyaneus], dotted grey line: Merlin [Falco columbarius]) or (b) across the whole study period (Common Buzzard [Buteo buteo]).
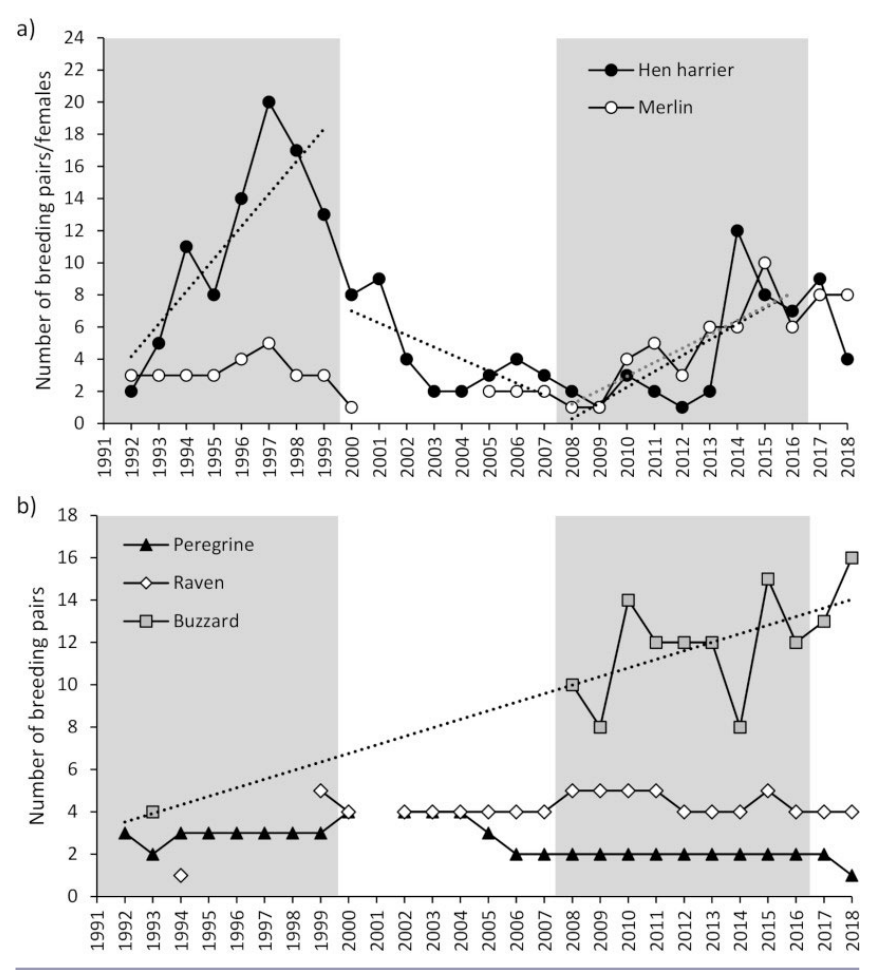

$=0.018)$. The latter showed no significant difference in trends between the different grouse moor management periods (year* period interaction: $\left.\mathrm{F}_{2,19}=0.33, \mathrm{p}=0.72\right)$, but a gradual overall increase of $8 \pm 2 \%$ per annum between 1992 and $2018\left(\mathrm{~F}_{1,25}=\right.$ 12.14, $\mathrm{p}=0.002$; Fig. 2).

\section{Breeding success}

In both periods when the moor was managed for Red Grouse, the average annual proportions of successful breeding attempts by ground-nesting raptors (Hen Harrier and Merlin) were two to three times higher than during the unmanaged period (Table 2, Fig. 3), which was not associated with changes in prey availability (Table 1). For Hen Harrier, this resulted in a two- to threefold increase in overall productivity, i.e., the number of young fledged breeding attempt $\mathrm{t}^{-1}$ (managed 1: $2.8 \pm 0.3$, unmanaged: $1.4 \pm 0.3$, managed 2: $\left.3.9 \pm 0.4 ; F_{2,22}=6.29, p=0.007\right)$, while this could not be tested for Merlin. Brood size of successful pairs did not differ in relation to whether the moor was managed for either species,
Fig. 2. Changes in abundance indices of Common Buzzards (Buteo buteo) obtained from Breeding Bird Surveys 1992-2018. Years with grouse-moor management are shaded grey (2008 considered unkeepered when analyzing breeding abundance). The trendline shows the significant linear trend across the whole study period.

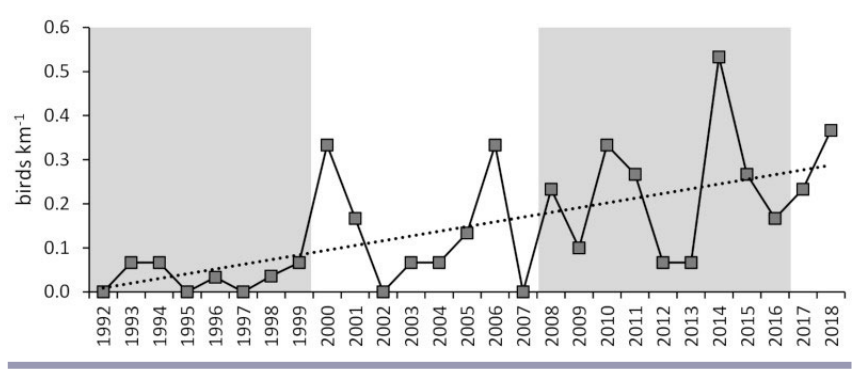

Fig. 3. Percentage of successful breeding attempts of groundnesting Hen Harrier (Circus cyaneus) and Merlin (Falco columbarius) during managed and unmanaged periods. Unmanaged periods (2000-2007 and 2017-2018) were pooled. Box plots show median (horizontal line within box), $25 \%$ and $75 \%$ percentiles (box) and range (whiskers), circles indicates outliers. See Table 2 for sample sizes.

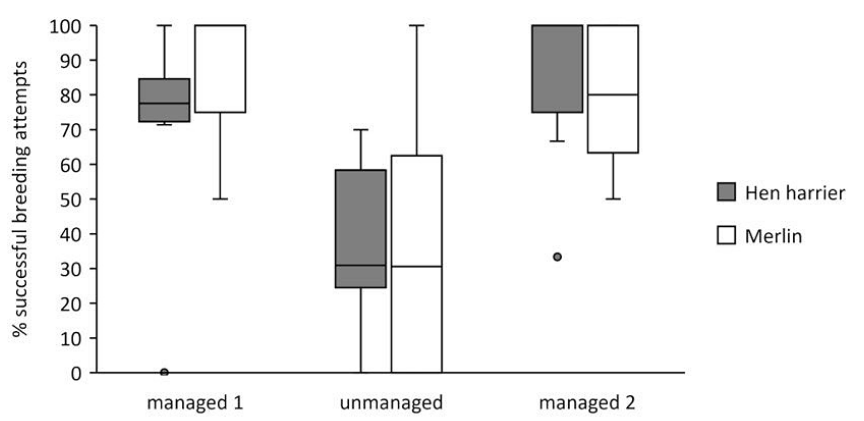

but Hen Harriers fledged on average one chick more during the second managed period than the first, while clutch sizes did not differ between periods $\left(\mathrm{F}_{2,23}=1.68, \mathrm{p}=0.21\right)$.

Breeding success of tree- or crag-nesting species (Peregrine, Buzzard, and Raven) did not follow the same pattern (Table 2). For Buzzard and Raven, neither the proportion of successful breeding attempts nor brood size differed across management periods. For Peregrine, however, the proportion of successful attempts tripled during the second managed period $(78 \%)$ in comparison to the preceding managed and unmanaged periods $(25 \%$ and $22 \%)$, while there was no difference in brood size. The number of young Peregrine fledged breeding attempt ${ }^{-1}$ did not differ between management periods (managed 1: $1.4 \pm 0.6$, unmanaged: $1.1 \pm 0.3$, managed 2: $1.9 \pm 0.3 ; \mathrm{F}_{2,15}=2.09, \mathrm{p}=$ 0.158).

\section{Apparent causes of breeding failure}

The breeding outcome was known for all 192 Hen Harrier breeding attempts; 130 attempts were successful and 62 failed (38 on eggs, 22 with chicks, and 2 at an unknown stage). Likely causes 
Table 2. Mean \pm SE percentage of successful breeding attempts, i.e., fledged at least one chick, and brood size of breeding raptors and Common Raven (Corvus corax) during managed and unmanaged periods. Unmanaged periods (2000-2007 and 2017-2018) were pooled. Sample sizes are given in brackets ( $\mathrm{N}=$ number of breeding attempts/broods). Different superscript letters indicate significant differences between periods based on t-statistics. Significant p-values are highlighted in bold.

\begin{tabular}{|c|c|c|c|c|c|}
\hline Species & Variable & Managed 1 & Unmanaged & Managed 2 & Test between periods \\
\hline Hen harrier & $\%$ successful & $71 \pm 11 \%^{\mathrm{a}}(8,95)$ & $38 \pm 7 \%{ }^{\mathrm{b}}(10,58)$ & $87 \pm 8 \%{ }^{\mathrm{a}}(9,39)$ & $F_{224}=9.80, \mathbf{p}<\mathbf{0 . 0 0 1}$ \\
\hline (Circus cyaneus) & Brood size & $3.3 \pm 0.2(7,75)$ & $3.2 \pm 0.4(9,23)$ & $4.5 \pm 0.3(9,32)$ & $\mathrm{F}_{2,22}^{2,24}=2.95, \mathrm{p}=0.073$ \\
\hline Merlin & $\%$ successful & $90 \pm 7 \%{ }^{a}(8,14)$ & $35 \pm 16 \% \%^{\mathrm{b}}(6,24)$ & $82 \pm 7 \%{ }^{\mathrm{a}}(9,35)$ & $\mathrm{F}_{2,20}^{2,22}=7.26, \mathbf{p}=\mathbf{0 . 0 0 4}$ \\
\hline $\begin{array}{l}\text { (Falco } \\
\text { columbarius) }\end{array}$ & Brood size & $3.6 \pm 0.3(8,9)$ & $2.8 \pm 0.9(3,6)$ & $4.0 \pm 0.4(9,17)$ & $\mathrm{F}_{2,17}^{2,20}=0.54, \mathrm{p}=0.590$ \\
\hline Peregrine & $\%$ successful & $25 \pm 12 \%^{\mathrm{a}}(8,22)$ & $22 \pm 8 \%^{\mathrm{a}}(9,24)$ & $78 \pm 9 \%^{b}(9,18)$ & $F_{2,3}=4.79, \mathbf{p}=\mathbf{0 . 0 1 8}$ \\
\hline $\begin{array}{l}\text { (Falco } \\
\text { peregrinus) }\end{array}$ & Brood size & $2.8 \pm 0.5(4,6)$ & $2.4 \pm 0.4(5,6)$ & $2.4 \pm 0.2(9,14)$ & $\mathrm{F}_{2,15}^{2,23}=0.42, \mathrm{p}=0.663$ \\
\hline Buzzard & $\%$ successful & - & $93 \pm 0.3 \%(2,27)$ & $87 \pm 5 \%(9,98)$ & $F_{19}=0.43, p=0.526$ \\
\hline $\begin{array}{l}\text { (Buteo } \\
\text { buteo) }\end{array}$ & Brood size & - & $2.1 \pm 0.5(2,14)$ & $1.8 \pm 0.1(9,61)$ & $\mathrm{F}_{1,9}^{1,}=1.51, \mathrm{p}=0.250$ \\
\hline \multirow[t]{2}{*}{ Raven } & $\%$ successful & - & $91 \pm 5 \%(9,32)$ & $91 \pm 5 \%(9,41)$ & $\mathrm{F}_{1,16}=0.00, \mathrm{p}=0.958$ \\
\hline & Brood size & - & $3.3 \pm 0.2(8,23)$ & $3.2 \pm 0.2(9,28)$ & $F_{1,15}^{1,16}=0.29, p=0.600$ \\
\hline
\end{tabular}

of failure were assigned to 36 breeding attempts (Table 3), of which $30(83 \%)$ failures were attributed to predation. Seven clutches, including three incubating females, and six broods were predated by fox. Four of these fox predation events were recorded in 1999, the last year of the first managed period when keepering ceased in February, the other nine occurred when the moor was not managed. No Hen Harrier attempts failed owing to fox predation during the second managed period. Other nest predators were corvids (two clutches), stoat, and Long-eared Owl (one brood each), the latter recorded by a nest camera. Five clutches and eight broods were taken by unknown predators. Six clutches were deserted (three following observer intervention during the unmanaged period, the other three belonged to secondary/tertiary females of polygynous males).

For Merlin, the outcome was known for 73 breeding attempts. Of these, 46 attempts were successful while 27 failed to fledge any chicks (13 on eggs, 8 with chicks, and 6 at an unknown stage), and likely causes of failure were assigned to 18 attempts (Table 3). Sixteen failures $(89 \%)$ were attributed to predation; identified predators were fox (five broods), corvid (two clutches), stoat (one clutch, including a male found dead on the nest) and raptor (one brood). Two of these fox predation events were recorded during the unmanaged period, and two in 2016, the last year of the second managed period when keepering ceased in February. Five clutches and two broods were taken by unknown predators. One further clutch was deserted and one failed to hatch.

The proportion of breeding failures on eggs and with chicks did not differ between managed and unmanaged periods for Hen Harrier $\left(\chi^{2}{ }_{1}=1.39, \mathrm{p}=0.24\right)$ or Merlin $\left(\chi^{2}{ }_{1}=1.62, \mathrm{p}=0.20\right)$, with $63 \%$ and $62 \%$ of failures occurring during the egg-stage (Table 3 ).

\section{Variation in prey abundance}

Red Grouse densities were higher when the moor was managed for Red Grouse (prebreeding: managed: $25.7 \pm 1.9$, unmanaged: $12.7 \pm 1.3, \mathrm{~F}_{1,23}=22.81, \mathrm{p}<0.001$; Red Grouse chicks: managed: $33.3 \pm 4.0$, unmanaged: $\left.7.3 \pm 1.4, \mathrm{~F}_{1,25}=23.26, \mathrm{p}<0.001\right)$, but not indices for passerines (managed: $20.0 \pm 1.8$, unmanaged: 24.2 $\pm 2.1 ; \mathrm{F}_{1,25}=2.13, \mathrm{p}=0.157$ ) or voles (managed: $2.3 \pm 0.5$, unmanaged: $1.3 \pm 0.2 ; \mathrm{F}_{1,25}=2.36, \mathrm{p}=0.137$ ). For annual variation in prey abundance indices see Fig. A2.1 in Appendix 2.

\section{DISCUSSION}

Breeding success of Hen Harrier and Merlin was two- to threetimes higher when the moor was managed for Red Grouse. This could be related to variation in either predation rates of breeding attempts, prey availability, or a combination of both (Hoy et al. 2016). Removal of generalist predators can increase breeding success in a range of bird species, particularly those nesting on the ground (Newton 1998, Fletcher et al. 2010, Smith et al. 2010), and predation has been identified as the main cause for Hen Harrier and Merlin nesting failure in this study and elsewhere (Rebecca et al. 1992, McMillan 2014). At Langholm, Hen Harrier breeding success was negatively associated with fox indices obtained from scat surveys, and when the moor was managed by gamekeepers, average abundance indices of foxes and Carrion Crows during the breeding season were $65 \%$ and $62 \%$ lower, respectively (Ludwig et al. 2017).

On the other hand, grouse moor management was associated with higher abundance of Red Grouse, but not passerines, the main prey of both Hen Harrier and Merlin (Redpath and Thirgood 1999, Heavisides et al. 2017), or voles. However, the proportion of successful Hen Harrier and Merlin breeding attempts was not associated with any of the measured prey abundance indices, and brood sizes at fledging (of successful attempts) did not differ between managed and unmanaged periods. This suggests that differences in Hen Harrier and Merlin breeding success between management periods were not related to variation in prey abundance, but instead to variation in rates of predation, which typically resulted in the loss of the whole clutch or brood. However, Hen Harriers fledged on average one chick more during the second managed period when all broods were provided with diversionary food, despite no differences in clutch sizes, suggesting that food supply can positively influence chick survival (Redpath et al. 2001, Ludwig et al. 2018b).

Hen Harrier breeding numbers showed positive trends during both periods of grouse moor management, but declined when the 
moor was unmanaged, while Merlin numbers showed a positive trend during only the second managed period but not the first. Baines and Richardson (2013) suggested that predation may limit Hen Harrier densities operating through reduced breeding success, which reduces the number of potential recruits. Females may also show increased breeding dispersal following nesting failure (Hakkarainen et al. 2001, Catlin and Rosenberg 2008), or possibly avoid areas with high predator densities (Roos and Pärt 2004). However, Hen Harrier numbers already started to decline before the end of both managed periods, peaking in 1997 and 2014, respectively (see Fig. 1), which suggests that other factors contributed to the observed changes in breeding numbers, possibly including density-dependent processes (e.g., Soutullo et al. 2006). In contrast to some larger raptors, Hen Harriers can start breeding in their first year $(68 \%$ of wing-tagged females; Etheridge et al. 1997), and populations may thus be able to respond quickly to environmental changes. However, as juvenile Hen Harriers show little natal site fidelity (Watson 1977, Etheridge et al. 1997), changes in breeding numbers are perhaps unlikely to be determined by local fledging success but more by external recruitment. The latter may have been limited by regional and national declines in range and abundance of Hen Harriers (Balmer et al. 2013, Wotton et al. 2018), which could also explain the delayed recovery in Hen Harrier numbers after grouse moor management resumed in 2008. Variation in abundance of adult Red Grouse, but not passerines or voles as shown in earlier studies (Redpath and Thirgood 1999, New et al. 2011), may have further contributed to the observed changes in Hen Harrier numbers. In contrast, changes in Merlin numbers were unrelated to the abundance of passerines, their main prey (Heavisides et al. 2017).

In contrast, grouse moor management was not associated with increases in breeding success or breeding numbers of tree- and crag-nesting Peregrine, Buzzard, and Raven, whose eggs and chicks are accessible to fewer mammalian predators but who also have a wider diet breadth compared to Hen Harrier and Merlin (Ratcliffe 1993, 1997, Francksen et al. 2016). Peregrine numbers showed little change on the current study area but increased from three to six pairs on a larger area studied during the early 1990 s (Redpath and Thirgood 1997). Since 2000, breeding numbers in the surroundings of Langholm Moor have declined again, in line with an overall $16 \%$ decline in the wider region, Dumfries and Galloway, between 2002 and 2014 (Wilson et al. 2018). Breeding success of Peregrines was low during both the first period of grouse moor management and the unmanaged period, with only $22-25 \%$ of pairs fledging chicks. This may have been associated with the temporary occupation of suboptimal territories and suspected human interference at one site at the boundary of the study area (M. Henderson, personal communication) in both periods. On the remaining two territories, breeding success then averaged $78 \%$ during the second managed period. Raven numbers increased from one pair in 1994 to five pairs in 1999, but then remained stable despite their ongoing national range expansion (Balmer et al. 2013, Wilson et al. 2019). Like Peregrines, Ravens are highly territorial, and relative stability of breeding numbers has been observed in many regions once the carrying capacity is reached (Ratcliffe 1997). The breeding density of five Raven pairs on $115 \mathrm{~km}^{2}$ at Langholm $\left(=4.3\right.$ pairs $\left.100 \mathrm{~km}^{-2}\right)$ was comparable to the average of 4.4 pairs $100 \mathrm{~km}^{-2}$ in southwest Scotland between 2003 and 2015 (Wilson et al. 2019). In contrast, Buzzard sighting rates increased throughout the study, and paralleled regional and national expansions in range and abundance (Holling 2003, Balmer et al. 2013).

Although Hen Harrier, Peregrine, and Raven were monitored systematically, it is possible that variation in monitoring effort may have contributed to the variation in breeding abundance of Merlin prior to 2008, possibly explaining why we did not detect a response during the first managed period, and of Buzzard from 2008 onward. However, breeding abundance of Buzzards was positively correlated with indices from breeding bird surveys, which were conducted throughout the study period and corroborated the observed changes in breeding abundance. Because Buzzard breeding attempts were not monitored from laying onward, we may have missed some attempts that failed early and thus overestimated breeding success.

Our study highlights that grouse moor management can benefit ground-nesting raptors such as Hen Harrier and Merlin, their breeding success being two to three times higher when gamekeepers were present. Given the nonexperimental design of this study, it was not possible to fully disentangle the potentially confounding effects of the different management components such as predator control, habitat management, or diversionary feeding, which may not only influence raptors directly but also indirectly via their prey species. However, grouse moor management had no apparent effect on passerine or vole abundance at Langholm, and differences in Red Grouse abundance between management periods were largely explained by predator control because neither breeding success nor survival were related with habitat management or heather cover (Ludwig et al. 2018a). Our data on management-related differences in predator indices and causes of breeding failures suggest that predator removal by gamekeepers may have been the main process influencing breeding success of Hen Harrier and Merlin. Nevertheless, additional factors may have contributed to changes in breeding abundance, including the higher availability of adult Red Grouse in the management periods positively influencing the recruitment of more female Hen Harriers.

Grouse moor management may thus not only reduce potential predators of nesting Hen Harriers, but may also attract more breeders by providing them with more food, i.e., Red Grouse. However, on a UK scale, these benefits for Hen Harriers are currently extensively outweighed by the impacts of illegal killing and nest destruction on rates of survival and productivity (Etheridge et al. 1997, Green and Etheridge 1999, Murgatroyd et al. 2019). Some studies also suggest that heather burning, which has increased in frequency on many grouse moors in England during the last decades (Yallop et al. 2006, Robertson et al. 2017), may reduce the availability of old heather stands preferred for nesting by both Hen Harrier and Merlin (Ewing et al. 2011, Heavisides et al. 2017) and of passerine prey such as Meadow Pipits (Smith et al. 2001, Pearce-Higgins and Grant 2006). However, at Langholm, where heather burning was resumed in 2008, the average heather height did not change between 2007 , prior to the restoration of management, and 2015 (Ludwig et al. 2018a), suggesting that the amount of tall heather was not limiting nest site availability to either species. Furthermore, potential negative effects of heather management on Meadow Pipit breeding abundance may be balanced by increases in their 
breeding success, together with increases of other prey such as Red Grouse and waders following predator control (Fletcher et al. 2010). On the other hand, our results showed that the abandonment of active management was associated with declines in Hen Harrier and Merlin breeding success as well as Hen Harrier abundance, which similarly impacted other ground-nesting birds of conservation concern (Baines et al. 2008, Fletcher et al. 2010, Ludwig et al. 2019). Cessation of grouse moor management may also accelerate the loss of heather moorland (Robertson et al. 2001), the predominant breeding habitat for both Hen Harrier and Merlin in the UK (Ewing et al. 2011, Wotton et al. 2018).

If the impact of Hen Harriers on Red Grouse, which underlies the motivation for illegal raptor control, could be reduced (see, e.g., Thirgood et al. 2000c, Redpath et al. 2010), it might be possible to improve the conservation status of Hen Harriers and other raptors while maintaining driven Red Grouse shooting. Previous studies on the same site, which showed that raptor predation can undermine grouse moor economics (Thirgood et al. 2000a, New et al. 2012), were carried out when the nematode worm Trichostrongylus tenuis, a gut parasite causing strongylosis in Red Grouse, was not controlled at Langholm. Now, routine use of medicated grit for strongyle control on many grouse moors, including Langholm from 2008 to 2014, reduces, but does not exclude, the likelihood of strongyle-induced Red Grouse population crashes (Baines et al. 2019, Newborn et al. 2019). Under these circumstances, the additive effect of Red Grouse predation by raptors is less certain, but still appeared sufficient to prevent Red Grouse recovery to economic levels at Langholm in the period 2008-2016 (Ludwig et al. 2018c).

Responses to this article can be read online at: http://www.ace-eco.org/issues/responses.php/1568

\begin{abstract}
Acknowledgments:
This study was conducted as part of the Langholm Moor Demonstration Project (2008-2017), funded by the Game \& Wildlife Conservation Trust, Scottish Natural Heritage, Buccleuch Estates, Royal Society for the Protection of Birds, and Natural England. We thank Buccleuch Estates for access and support throughout the study period. We are grateful to the members of the local Scottish Raptor Study Groups for their invaluable assistance in the field and contribution of data, especially C. Barlow, K. Bell, J. Halliday, M. Henderson, M. Hotson, T. Lightly, G. Smith, R. Taylor, A. Walton, and J. Wright. We also thank the numerous field assistants and students who helped with monitoring, including E. Aimes, J. Butler, T. Chamberlain, E. Colver, R. Francksen, P. Golder, K. Hazelwood, P. Keane, A. McCluskie, A. McWilliam, A. Paul, T. Pringle, and E. Rooney. N. Aebischer, E. Blomberg, I. Newton, D. Thompson, J. Wilson, and two anonymous reviewers provided helpful comments on earlier versions of this manuscript.
\end{abstract}

\section{LITERATURE CITED}

Amar, A., I. R. Court, M. Davison, S. Downing, T. Grimshaw, T. Pickford, and D. Raw. 2012. Linking nest histories, remotely sensed land use data and wildlife crime records to explore the impact of grouse moor management on Peregrine Falcon populations. Biological Conservation 145:86-94. https://doi.org/10.1016/j. biocon.2011.10.014

Baines, D., D. Newborn, and M. Richardson. 2019. Are Trichostrongylus tenuis control and resistance avoidance simultaneously manageable by reducing anthelmintic intake by grouse? Veterinary Record 185:53. https://doi.org/10.1136/ vr.105029

Baines, D., S. Redpath, M. Richardson, and S. Thirgood. 2008. The direct and indirect effects of predation by Hen Harriers Circus cyaneus on trends in breeding birds on a Scottish grouse moor. Ibis 150:27-36. https://doi.org/10.1111/j.1474-919X.2008.00848. $\mathrm{x}$

Baines, D., and M. Richardson. 2013. Hen Harriers on a Scottish grouse moor: multiple factors predict breeding density and productivity. Journal of Applied Ecology 50:1397-1405. https:// doi.org/10.1111/1365-2664.12154

Balmer, D., S. Gillings, B. Caffrey, B. Swann, I. Downie, and R. Fuller. 2013. Bird Atlas 2007-11. The breeding and wintering birds of Britain and Ireland. BTO Books, Thetford, UK.

Bodey, T. W., R. A. McDonald, R. D. Sheldon, and S. Bearhop. 2011. Absence of effects of predator control on nesting success of Northern Lapwings Vanellus vanellus: implications for conservation. Ibis 153:543-555. https://doi.org/10.1111/ j.1474-919X.2011.01132.x

Catlin, D. H., and D. K. Rosenberg. 2008. Breeding dispersal and nesting behavior of burrowing owls following experimental nest predation. American Midlands Naturalist 159:1-7. https://doi. org/10.1674/0003-0031(2008)159[1:BDANBO]2.0.CO;2

Chakarov, N., and O. Krüger. 2010. Mesopredator release by an emergent superpredator: a natural experiment of predation in a three level guild. PLoS ONE 5:e15229. https://doi.org/10.1371/ journal.pone.0015229

Cramp, S., and K. E. L. Simmons. 1980. Handbook of the birds of Europe, the Middle East and North Africa: the birds of the Western Palearctic. Vol. 2. Oxford University Press, Oxford, UK.

Douglas, D. J. T., P. E. Bellamy, L. S. Stephen, J. W. PearceHiggins, J. D. Wilson, and M. C. Grant. 2014. Upland land use predicts population decline in a globally near-threatened wader. Journal of Applied Ecology 51:194-203. https://doi.

org/10.1111/1365-2664.12167

Etheridge, B., R. W. Summers, and R. E. Green. 1997. The effects of illegal killing and destruction of nests by humans on the population dynamics of the Hen Harrier Circus cyaneus in Scotland. Journal of Applied Ecology 34:1081-1105. https://doi. org/10.2307/2405296

Ewing, S. R., G. W. Rebecca, A. Heavisides, I. R. Court, P. Lindley, M. Ruddock, S. Cohen, and M. A. Eaton. 2011. Breeding status of Merlins Falco columbarius in the UK in 2008. Bird Study 58:379-389. https://doi.org/10.1080/00063657.2011.606497

Fletcher, K., N. J. Aebischer, D. Baines, R. Foster, and A. N. Hoodless. 2010. Changes in breeding success and abundance of ground-nesting moorland birds in relation to the experimental deployment of legal predator control. Journal of Applied Ecology 47:263-272. https://doi.org/10.1111/j.1365-2664.2010.01793.x 
Francksen, R. M., M. J. Whittingham, and D. Baines. 2016. Assessing prey provisioned to Common Buzzard Buteo buteo chicks: a comparison of methods. Bird Study 63:303-310. https:// doi.org/10.1080/00063657.2016.1183111

Graham, I. M., S. M. Redpath, and S. J. Thirgood. 1995. The diet and breeding density of Common Buzzards Buteo buteo in relation to indices of prey abundance. Bird Study 42:165-173. https://doi.org/10.1080/00063659509477162

Green, R. E., and B. Etheridge. 1999. Breeding success of the Hen Harrier Circus cyaneus in relation to the distribution of grouse moors and the red fox Vulpes vulpes. Journal of Applied Ecology 36:472-483. https://doi.org/10.1046/j.1365-2664.1999.00419.x

Green, R. E., J. Hawell, and T. H. Johnson. 1987. Identification of predators of wader eggs from egg remains. Bird Study 34:87-91. https://doi.org/10.1080/00063658709476940

Hakkarainen, H., P. Ilmonen, V. Koivunen, and E. Korpimäki. 2001. Experimental increase of predation risk induces breeding dispersal of Tengmalm's Owl. Oecologia 126:355-359. https://doi. org/10.1007/s004420000525

Hardey, J., H. Crick, C. Wernham, H. Riley, B. Etheridge, and D. Thompson. 2013. Raptors. A field guide for surveys and monitoring. The Stationery Office, Edinburgh, UK.

Harris, S. J., D. Massimino, S. Gillings, M. A. Eaton, D. G. Noble, D. E. Balmer, D. Procter, J. W. Pearce-Higgins, and P. Woodcock. 2018. The Breeding Bird Survey 2017. BTO Research Report 706. British Trust for Ornithology, Thetford, UK.

Heavisides, A., A. Barker, and I. Poxton. 2017. Population and breeding biology of Merlins in the Lammermuir Hills. British Birds 110:138-154.

Holling, M. 2003. Buzzards (Buteo buteo) on the increase in Lothain and Borders, Scotland. Pages 173-178 in D. B. A. Thompson, S. M. Redpath, A. H. Fielding, M. Marquiss, and C. A. Galbraith, editors. Birds of prey in a changing environment. The Stationary Office, Edinburgh, UK.

Hoy, S. R., A. Millon, S. J. Petty, D. P. Whitfield, and X. Lambin. 2016. Food availability and predation risk, rather than intrinsic attributes, are the main factors shaping the reproductive decisions of a long-lived predator. Journal of Animal Ecology 85:892-902. https://doi.org/10.1111/1365-2656.12517

Hudson, P. J., A. P. Dobson, and D. Newborn. 1998. Prevention of population cycles by parasite removal. Science 282:2256-2258. https://doi.org/10.1126/science.282.5397.2256

Hudson, P. J., and D. Newborn. 1995. Red Grouse and moorland management. Game Conservancy Trust, Fordingbridge, UK.

Korpimaki, E., and K. Norrdahl. 1991. Numerical and functional responses of Kestrels, Short-eared Owls, and Long-eared Owls to vole densities. Ecology 72:814-826. https://doi.org/10.2307/1940584

Ludwig, S. C., N. J. Aebischer, D. Bubb, M. Richardson, S. Roos, J. D. Wilson, and D. Baines. 2018a. Population responses of Red Grouse Lagopus lagopus scotica to expansion of heather Calluna vulgaris cover on a Scottish grouse moor. Avian Conservation and Ecology 13(2):14. https://doi.org/10.5751/ace-01306-130214
Ludwig, S. C., N. J. Aebischer, D. Bubb, S. Roos, and D. Baines. 2018c. Survival of chicks and adults explains variation in population growth in a recovering Red Grouse Lagopus lagopus scotica population. Wildlife Biology 2018:wlb.00430. https://doi. org/10.2981/wlb.00430

Ludwig, S. C., A. McCluskie, P. Keane, C. Barlow, R. M. Francksen, D. Bubb, S. Roos, N. J. Aebischer, and D. Baines. 2018b. Diversionary feeding and nestling diet of Hen Harriers Circus cyaneus. Bird Study 65:431-443. https://doi. org/10.1080/00063657.2018.1519524

Ludwig, S. C., S. Roos, and D. Baines. 2019. Responses of breeding waders to restoration of grouse management on a moor in south-west Scotland. Journal of Ornithology 160:789-797. https://doi.org/10.1007/s10336-019-01667-6

Ludwig, S. C., S. Roos, D. Bubb, and D. Baines. 2017. Long-term trends in abundance and breeding success of Red Grouse and Hen Harriers in relation to changing management of a Scottish grouse moor. Wildlife Biology 2017:wlb.00246. https://doi.org/10.2981/ wlb.00246

McMillan, R. L. 2014. Hen Harriers on Skye, 2000-12: nest failures and predation. Scottish Birds 34:30-39.

Murgatroyd, M., S. M. Redpath, S. G. Murphy, D. J. T. Douglas, R. Saunders, and A. Amar. 2019. Patterns of satellite tagged Hen Harrier disappearances suggest widespread illegal killing on British grouse moors. Nature Communications 10:1094. https:// doi.org/10.1038/s41467-019-09044-w

New, L. F., S. T. Buckland, S. Redpath, and J. Matthiopoulos. 2011. Hen harrier management: insights from demographic models fitted to population data. Journal of Applied Ecology 48:1187-1194. https://doi.org/10.1111/j.1365-2664.2011.02013.x

New, L. F., S. T. Buckland, S. Redpath, and J. Matthiopoulos. 2012. Modelling the impact of Hen Harrier management measures on a Red Grouse population in the UK. Oikos 121:1061-1072. https://doi.org/10.1111/j.1600-0706.2011.19958.

\section{$\mathrm{x}$}

Newborn, D., D. Baines, K. Fletcher, N. Hesford, M. Richardson, and P. Warren. 2019. Uplands monitoring in 2018. Annual Review of the Game \& Wildlife Conservation Trust 50:60-63.

Newborn, D., and R. Foster. 2002. Control of parasite burdens in wild Red Grouse Lagopus lagopus scoticus through the indirect application of anthelmintics. Journal of Applied Ecology 39:909-914. https://doi.org/10.1046/j.1365-2664.2002.00771.x

Newton, I. 1979. Population ecology of raptors. T \& AD Poyser, Berkhamsted, UK.

Newton, I. 1998. Population limitation in birds. Academic, London, UK.

Newton, I. 2003. The role of natural factors in the limitation of birds of prey numbers: a brief review of the evidence. Pages 5-23 in D. B. A. Thompson, S. M. Redpath, A. H. Fielding, M. Marquiss, and C. A. Galbraith, editors. Birds of prey in a changing environment. The Stationary Office, Edinburgh, UK.

Newton, I., E. R. Meek, and B. Little. 1978. Breeding ecology of the Merlin in Northumberland. British Birds 71:376-398. 
Newton, I., E. R. Meek, and B. Little 1984. Breeding season foods of Merlins Falco columbarius in Northumbria. Bird Study 31:49-56. https://doi.org/10.1080/00063658409476815

Nielsen, Ó. K. 1999. Gyrfalcon predation on ptarmigan: numerical and functional responses. Journal of Animal Ecology 68:1034-1050. https://doi.org/10.1046/j.1365-2656.1999.00351.x

Pearce-Higgins, J. W. and M. C. Grant. 2006. Relationships between bird abundance and the composition and structure of moorland vegetation. Bird Study 53:112-125. https://doi. org/10.1080/00063650609461424

Petty, S. J., D. I. K. Anderson, M. Davison, B. Little, T. N. Sherratt, C. J. Thomas, and X. Lambin. 2003. The decline of Common Kestrels Falco tinnunculus in a forested area of northern England: the role of predation by Northern Goshawks Accipiter gentilis. Ibis 145:472-483. https://doi.org/10.1046/j.1474-919X.2003.00191. $\mathrm{x}$

Porteus, T. A., J. C. Reynolds, and M. K. McAllister. 2019. Population dynamics of foxes during restricted-area culling in Britain: advancing understanding through state-space modelling of culling records. PLOS ONE 14:e0225201. https://doi. org/10.1371/journal.pone.0225201

Pringle, H., M. Wilson, J. Calladine, and G. Siriwardena. 2019. Associations between gamebird releases and generalist predators. Journal of Applied Ecology 56:2102-2113. https://doi. org/10.1111/1365-2664.13451

Ratcliffe, D. 1993. The Peregrine Falcon. T \& AD Poyser, Berkhamsted, UK.

Ratcliffe, D. A. 1997. The raven. A natural history in Britain and Ireland. T \& AD Poyser, Berkhamsted, UK.

Rebecca, G. W., B. L. Cosnette, J. J. C. Hardey, and A. G. Payne. 1992. Status, distribution and breeding biology of the Merlin in north-east Scotland, 1980-1989. Scottish Birds 16:165-183.

Redpath, C. J., S. J. Thirgood, and S. M. Redpath. 1995. Evaluation of methods to estimate field vole Microtus agrestis abundance in upland habitats. Journal of Zoology 237:49-55. https://doi.org/10.1111/j.1469-7998.1995.tb02745.x

Redpath, S., A. Amar, M. Madders, F. Leckie, and S. Thirgood. 2002. Hen Harrier foraging success in relation to land use in Scotland. Animal Conservation 5:113-118. https://doi.org/10.1017/ S1367943002002159

Redpath, S. M., A. Amar, A. Smith, D. Thompson, and S. J. Thirgood. 2010. People and nature in conflict: can we reconcile Hen Harrier conservation and game management? Pages 335-350 in J. Baxter, and C. A. Galbraith, editors. Species management: challenges and solutions for the 21 st century. The Stationary Office, Edinburgh, UK.

Redpath, S. M., and S. J. Thirgood. 1997. Birds of prey and Red Grouse. The Stationery Office, Edinburgh, UK.

Redpath, S. M., and S. J. Thirgood. 1999. Numerical and functional responses in generalist predators: Hen Harriers and Peregrines on Scottish grouse moors. Journal of Animal Ecology 68:879-892. https://doi.org/10.1046/j.1365-2656.1999.00340.x
Redpath, S. M., S. J. Thirgood, and F. M. Leckie. 2001. Does supplementary feeding reduce predation of Red Grouse? Journal of Applied Ecology 38:1157-1168. https://doi.org/10.1046/ j.0021-8901.2001.00683.x

Robertson, G. S., D. Newborn, M. Richardson, and D. Baines. 2017. Does rotational heather burning increase Red Grouse abundance and breeding success on moors in northern England? Wildlife Biology 2017:wlb.00227. https://doi.org/10.2981/wlb.00227

Robertson, P. A., K. J. Park, and A. F. Barton. 2001. Loss of heather Calluna vulgaris moorland in the Scottish uplands: the role of Red Grouse Lagopus lagopus scoticus management. Wildlife Biology 7:11-16. https://doi.org/10.2981/wlb.2001.004

Roos, S. and T. Pärt. 2004. Nest predators affect spatial dynamics of breeding Red-backed Shrikes (Lanius collurio). Journal of Animal Ecology 73:117-127. https://doi.org/10.1111/ j.1365-2656.2004.00786.x

Roos, S., J. Smart, D. W. Gibbons, and J. D. Wilson. 2018. A review of predation as a limiting factor for bird populations in mesopredator-rich landscapes: a case study of the UK. Biological Reviews 93:1915-1937. https://doi.org/10.1111/brv.12426

Salamolard, M., A. Butet, A. Leroux, and V. Bretagnolle. 2000. Responses of an avian predator to variations in prey density at a temperate latitude. Ecology 81:2428-2441. https://doi. org/10.1890/0012-9658(2000)081[2428:roaapt]2.0.co;2

Seber, G. A. F. 1982. Estimation of animal abundance and related parameters. Griffin, London, UK.

Sergio, F., and F. Hiraldo. 2008. Intraguild predation in raptor assemblages: a review. Ibis 150:132-145. https://doi.org/10.1111/ j.1474-919X.2008.00786.x

Sergio, F., L. Marchesi, and P. Pedrini. 2003. Spatial refugia and the coexistence of a diurnal raptor with its intraguild owl predator. Journal of Animal Ecology 72:232-245. https://doi.org/10.1046/ j.1365-2656.2003.00693.x

Smith, A. A., S. M. Redpath, S. T. Campbell, and S. J. Thirgood. 2001. Meadow Pipits, Red Grouse and the habitat characteristics of managed grouse moors. Journal of Applied Ecology 38:390-400. https://doi.org/10.1046/j.1365-2664.2001.00601.x

Smith, R. K., A. S. Pullin, G. B. Stewart, and W. J. Sutherland. 2010. Effectiveness of predator removal for enhancing bird populations. Conservation Biology 24:820-829. https://doi. org/10.1111/j.1523-1739.2009.01421.x

Söderström, B., T. Pärt, and J. Rydén. 1998. Different nest predator faunas and nest predation risk on ground and shrub nests at forest ecotones: an experiment and a review. Oecologia 117:108-118. https://doi.org/10.1007/s004420050638

Soutullo, A., R. Limiñana, V. Urios, M. Surroca, and J. A. Gill. 2006. Density-dependent regulation of population size in colonial breeders: Allee and buffer effects in the migratory Montagu's Harrier. Oecologia 149:543-552. https://doi.org/10.1007/ s00442-006-0465-5

Stroud, D. A. 2003. The status and legislative protection of birds of prey and their habitat in Europe. Pages 51-84 in D. B. A. Thompson, S. M. Redpath, A. H. Fielding, M. Marquiss, and C. 
A. Galbraith, editors. Birds of prey in a changing environment. The Stationary Office, Edinburgh, UK.

Summers, R. W., R. E. Green, B. Etheridge, and I. M. W. Sim. 2003. Changes in Hen Harrier (Circus cyaneus) numbers in relation to grouse moor management. Pages 487-497 in D. B. A. Thompson, S. M. Redpath, A. H. Fielding, M. Marquiss, and C. A. Galbraith, editors. Birds of prey in a changing environment. The Stationary Office, Edinburgh, UK.

Tharme, A. P., R. E. Green, D. Baines, I. P. Bainbridge, and M. O'Brien. 2001. The effect of management for Red Grouse shooting on the population density of breeding birds on heatherdominated moorland. Journal of Animal Ecology 38:439-457. https://doi.org/10.1046/j.1365-2664.2001.00597.x

Thirgood, S. J., F. M. Leckie, and S. M. Redpath. 1995. Diurnal and seasonal variation in line transect counts of moorland passerines. Bird Study 42:257-259. https://doi.org/10.1080/00063659509477177

Thirgood, S. J., and S. M. Redpath. 2000. Can raptor predation limit Red Grouse populations? Pages 527-534 in R. D. Chancellor and B.-U. Meyburg, editors. Raptors at risk. WWGBP, Hancock House, Surry, British Columbia, Canada.

Thirgood, S. J., S. M. Redpath, D. T. Haydon, P. Rothery, I. Newton, and P. J. Hudson. 2000b. Habitat loss and raptor predation: disentangling long- and short-term causes of Red Grouse declines. Proceedings of the Royal Society B 267:651-656. https://doi.org/10.1098/rspb.2000.1051

Thirgood, S. J., S. M. Redpath, P. J. Hudson, and E. Donnelly. 1998. Estimating the cause and rate of mortality in Red Grouse Lagopus lagopus scoticus. Wildlife Biology 4:65-71. https://doi. org/10.2981/wlb.1998.002

Thirgood, S. J., S. M. Redpath, I. Newton, and P. J. Hudson. 2000c. Raptors and Red Grouse: conservation conflicts and management solutions. Conservation Biology 14:95-104. https:// doi.org/10.1046/j.1523-1739.2000.99013.x

Thirgood, S. J., S. M. Redpath, P. Rothery, and N. J. Aebischer. 2000a. Raptor predation and population limitation in Red Grouse. Journal of Animal Ecology 69:504-516. https://doi. org/10.1046/j.1365-2656.2000.00413.x

VSN International. 2018. GenStat for Windows 19th Edition. VSN International, Hemel Hempstead, UK.

Watson, D. 1977. The Hen Harrier. T. \& A.D. Poyser, Berkhamstedt, UK.

Whitfield, D. P., and A. H. Fielding. 2017. Analyses of the fates of satellite tracked Golden Eagles in Scotland. SNH Commissioned Report No. 982. Scottish Natural Heritage, Edinburgh, UK.
Wilson, M. W., D. E. Balmer, K. Jones, V. A. King, D. Raw, C. J. Rollie, E. Rooney, M. Ruddock, G. D. Smith, A. Stevenson, P. K. Stirling-Aird, C. V. Wernham, J. M. Weston, and D. G. Noble. 2018. The breeding population of Peregrine Falcon Falco peregrinus in the United Kingdom, Isle of Man and Channel Islands in 2014. Bird Study 65:1-19. https://doi.org/10.1080/00063657.2017.1421610

Wilson, M. W., A. S. C. P. Cook, C. Horswill, R. A. Robinson, and C. V. Wernham. 2019. Population modelling for the Scottish Northern Raven population. SNH Research Report No. 1012. Scottish Natural Heritage, Edinburgh, UK.

Wotton, S. R., S. Bladwell, W. Mattingley, N. G. Morris, D. Raw, M. Ruddock, A. Stevenson, and M. A. Eaton. 2018. Status of the Hen Harrier Circus cyaneus in the UK and Isle of Man in 2016. Bird Study 65:145-160. https://doi.org/10.1080/00063657.2018.1476462

Yallop, A. R., J. I. Thacker, G. Thomas, M. Stephens, B. Clutterbuck, T. Brewer, and C. A. D. Sannier. 2006. The extent and intensity of management burning in the English uplands. Journal of Applied Ecology 43:1138-1148. https://doi.org/10.1111/ j.1365-2664.2006.01222.x
Editor-in-Chief: Keith A.Hobson Subject Editor: Erik Blomberg
Sponsored by the Society of Canadian Ornithologists and Birds Canada

Parrainée par la Société des ornithologistes du Canada et Oiseaux Canada

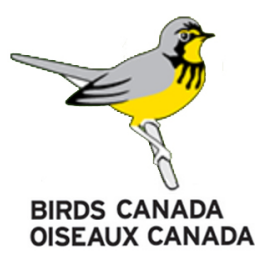


Avian Conservation and Ecology 15(1): 21

http://www.ace-eco.org/vol15/iss1/art21/ 
Avian Conservation and Ecology 15(1): 21

http://www.ace-eco.org/vol15/iss1/art21/ 
Table 3. Outcome of Hen Harrier (Circus cyaneus) and Merlin (Falco columbarius) breeding attempts of known fate, and likely causes of breeding failure, in managed (1992-1999 and 2008-2016) and unmanaged (2000-2007 and 2017-2018) periods. Clutches or broods disappearing without signs were classified as unknown predator. Note that almost all fox predation in the managed period occurred during the final year of keepering in each period, when fox control ceased in early spring (see text).

\begin{tabular}{|c|c|c|c|c|}
\hline & \multicolumn{2}{|c|}{ Hen Harrier } & \multicolumn{2}{|c|}{ Merlin } \\
\hline & $\begin{array}{c}\text { Managed } \\
\mathrm{N}(\%)\end{array}$ & $\begin{array}{c}\text { Unmanaged } \\
\mathrm{N}(\%)\end{array}$ & $\begin{array}{c}\text { Managed } \\
\mathrm{N}(\%)\end{array}$ & $\begin{array}{c}\text { Unmanaged } \\
\mathrm{N}(\%)\end{array}$ \\
\hline Attempts of known fate & 134 & 58 & 49 & 24 \\
\hline Failed & $27(20 \%)$ & $35(60 \%)$ & $10(20 \%)$ & $17(71 \%)$ \\
\hline Failed with eggs & $18(67 \%)$ & $20(57 \%)$ & $3(30 \%)$ & $10(59 \%)$ \\
\hline Deserted & 3 & 3 & 0 & 1 \\
\hline Did not hatch & 0 & 0 & 0 & 1 \\
\hline Fox & 3 ( +1 female $)$ & $4(+1$ female $)$ & 0 & 0 \\
\hline Stoat & 0 & 0 & $1(+1$ male $)$ & 0 \\
\hline Corvid & 2 & 0 & 0 & 2 \\
\hline Unknown predator & 2 & 3 & 1 & 4 \\
\hline Unknown & 8 & 10 & 1 & 2 \\
\hline Failed with chicks & $7(26 \%)$ & $15(43 \%)$ & $4(40 \%)$ & $4(24 \%)$ \\
\hline Fox & 1 (+1 female $)$ & 5 & 3 & 2 \\
\hline Stoat & 1 & 0 & 0 & 0 \\
\hline Raptor/owl & 0 & 1 & 1 & 0 \\
\hline Unknown predator & 0 & 8 & 0 & 2 \\
\hline Unknown & 5 & 1 & 0 & 0 \\
\hline Failed unknown stage & $2(7 \%)$ & 0 & $3(30 \%)$ & $3(17 \%)$ \\
\hline
\end{tabular}




\section{Appendix 1.}

Table A1.1 Model output for the calculation of trends in breeding abundance within each management period (Hen Harrier, Merlin) or across the whole study period (Peregrine, Buzzard, Raven).

\begin{tabular}{|c|c|c|c|c|c|c|}
\hline Species & Period & Variables & Estimate & SE & $t$ & $\mathbf{P}$ \\
\hline \multirow[t]{6}{*}{ Hen Harrier } & 1992-1999 & Intercept & -370.0 & 128.0 & -2.90 & 0.027 \\
\hline & & Year & 0.1866 & 0.0639 & 2.92 & 0.027 \\
\hline & $2000-2007$ & Intercept & 356.0 & 140.0 & 2.54 & 0.044 \\
\hline & & Year & -0.1772 & 0.0702 & -2.53 & 0.045 \\
\hline & $2008-2016$ & Intercept & -507.0 & 182.0 & -2.79 & 0.027 \\
\hline & & Year & 0.2525 & 0.0902 & 2.80 & 0.026 \\
\hline \multirow[t]{5}{*}{ Merlin } & 1992-1999 & Intercept & -48.1 & 67.2 & -0.72 & 0.501 \\
\hline & & Year & 0.0247 & 0.0337 & 0.73 & 0.491 \\
\hline & $2000-2007$ & Insufficient data & - & - & - & - \\
\hline & $2008-2016$ & Intercept & -391.0 & 110.0 & -3.56 & 0.009 \\
\hline & & Year & 0.1952 & 0.0546 & 3.58 & 0.009 \\
\hline \multirow[t]{2}{*}{ Peregrine } & $1992-2018$ & Intercept & 49.7 & 31.2 & 1.59 & 0.111 \\
\hline & & Year & -0.0243 & 0.0156 & -1.56 & 0.118 \\
\hline \multirow[t]{4}{*}{ Buzzard } & 1993-2018 (pairs) & Intercept & -90.1 & 23.5 & -3.84 & 0.003 \\
\hline & & Year & 0.0460 & 0.0117 & 3.95 & 0.003 \\
\hline & 1992-2018 (BBS) & Intercept & -156.6 & 44.4 & -3.52 & 0.002 \\
\hline & & Year & 0.0770 & 0.0221 & 3.48 & 0.002 \\
\hline \multirow[t]{2}{*}{ Raven } & $1994-2018$ & Intercept & -26.0 & 35.1 & -0.74 & 0.458 \\
\hline & & Year & 0.0137 & 0.0175 & 0.78 & 0.434 \\
\hline
\end{tabular}




\section{Appendix 2.}
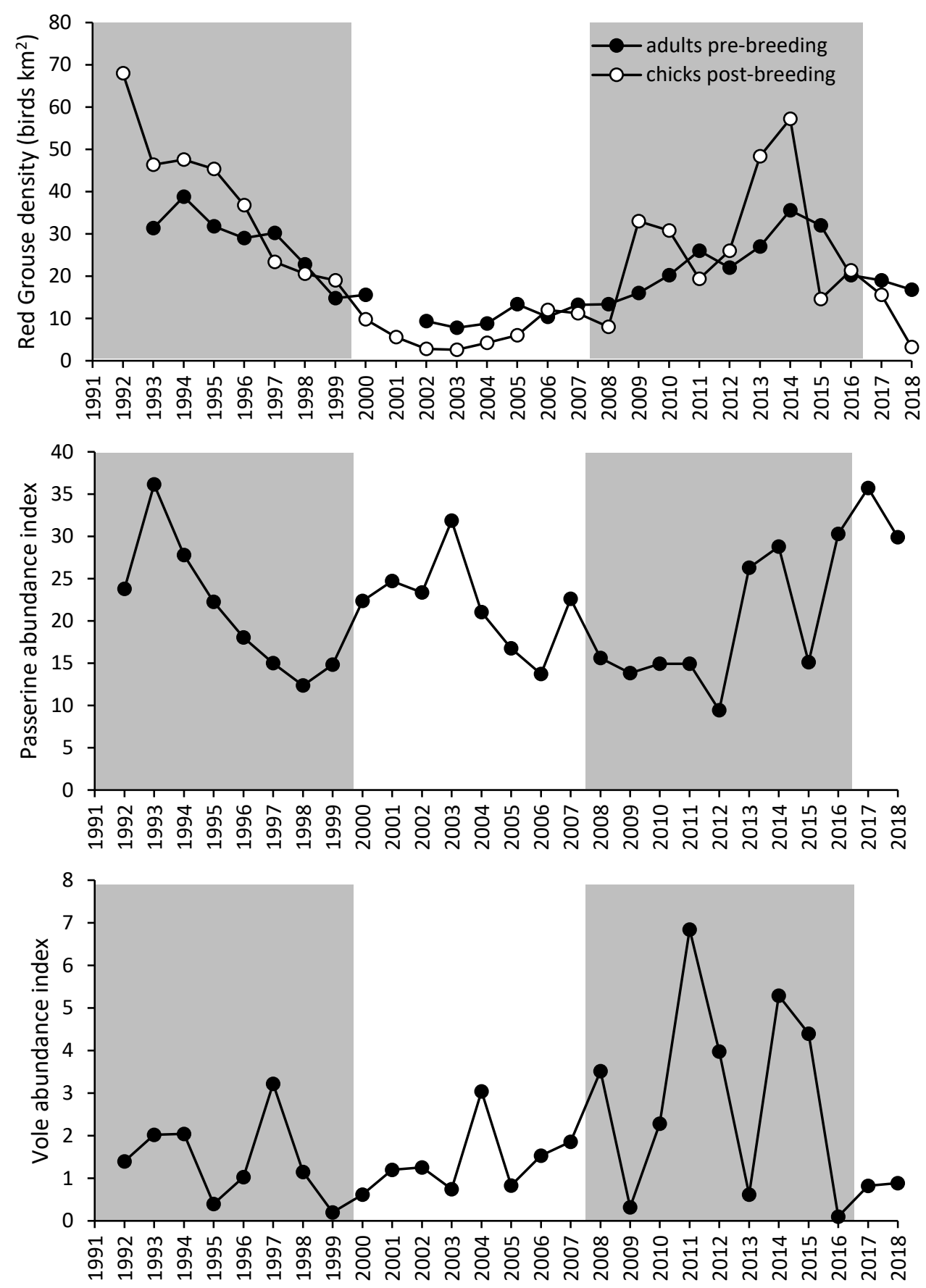

Figure A2.1. Annual variation in prey abundance indices at Langholm 1992-2018; a) Red Grouse (birds km $\mathrm{k}^{-2}$ ), b) passerines (Meadow Pipits and Skylarks km${ }^{-1}$ ), c) voles (field voles 100 trap nights $^{-1}$ ). Years with grouse-moor management, which involves predator control, are shaded grey. 